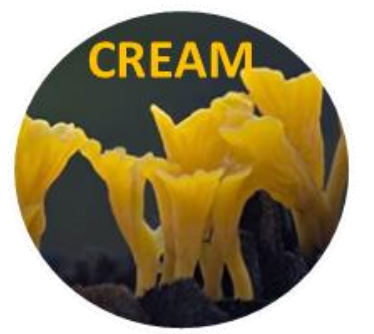

\title{
Some new additions to black mildew fungi of North Western Himalayas, India
}

\author{
Gautam $\mathrm{AK}^{1^{*}}$ and Avasthi $\mathrm{S}^{2}$ \\ ${ }^{1}$ Faculty of Agriculture, Abhilashi University, Mandi-175028, India \\ ${ }^{2}$ Department of Botany, Abhilashi Institute of Life Sciences, Mandi- 175008, India
}

Gautam AK, Avasthi S 2016 - Some new additions to black mildew fungi of North Western Himalayas, India. Current Research in Environmental \& Applied Mycology 6(1), 111-117, Doi $10.5943 /$ cream/6/2/5

\begin{abstract}
Three black mildew fungi, namely Schiffnerula celastri, Sarcinella oreophila and Schiffnerula cryptostegiae were reported on Celastrus paniculatus, Carissa sp. and Cryptolepis buchanani respectively and are described and illustrated in detail in the present study. Although, these black mildews have previously been reported from various parts of India, there is no report from Himachal Pradesh and surrounding areas. Therefore, the present study contributes new records to the black mildew fungi, not only in the state, but also in the north western Himalaya.
\end{abstract}

Key words - Black mildews - Himachal Pradesh - India - Schiffnerula - Sarcinella - taxonomy

\section{Introduction}

Black mildews are fungi that produce black colonies on the host surface. These fungi are ectotrophic, obligate parasites that inhabit moist humid environments in tropical and sub-tropical regions. They occur on higher plants and infect mostly soft stems, petioles and leaves. The fungi are believed to be host-specific and produce beautiful web-like structures, appressoria, setae, thyrotecia, pycnothyria, asci, ascospores, pycnothyriospores, perithecial appendages and brown septate ascospores on infected hosts. These fungi can be categorized in several taxonomic groups, viz. meliolaceous fungi, schiffnerulaceous fungi, asterinaceous fungi, hyphomycetous fungi (Hansford 1961, Hosagoudar 2008, Hosagoudar \& Agarwal 2008).

During explorations of foliicolous fungi in the Himachal Pradesh, India, some black mildew fungi infecting host plants were collected from various localities of Mandi and Bilaspur districts of the state. The variable climatic and topographical conditions of the state provide best favorable conditions for the luxuriant growth and development of foliicolous fungi. This northern Himalayan state is known for its rich biodiversity and has been explored to a large extent for mycorrhizal fungi, rusts, powdery mildews and to some extent hyphomycetes. However there is little information available on Black mildews. Hence, we have taken an interest in the systematic study of black mildews in the state.

\section{Materials \& Methods}

Infected plant parts were observed in the field, field notes were made regarding their pathogenicity, nature of colonies, nature of infection, locality, and altitude. In the field, infected plants were collected separately in polythene bags. These infected plant parts were pressed neatly and dried in between blotting papers. After ensuring their dryness, they were kept in the manifold or butter paper 
folders. The type specimens have been deposited in Faculty of Agriculture, Abhilashi Univertsity (AUMH), Himachal Pradesh, India.

For microscopic study, scrapes were taken directly from the infected host and mounted in $10 \%$ $\mathrm{KOH}$ solution. After 30 minutes, $\mathrm{KOH}$ was replaced by lactophenol for clear visibility of septa. Nail polish technique was used to study the colonies in the natural conditions. A drop of clear, transparent high quality natural nail polish was applied to the selected colonies as thin layer with a fine brush and kept in dust free chamber for 30 minutes. The thin film or flip formed after dryness was lifted off with a slight pressure on the opposite side of the leaves or with the help of a razor or scalpel. The thin film or flip was mounted in a drop of DPX (A mixture of Distyrene, a plasticizer and xylene) on a clean glass slide and used for observation and retained (Hosagoudar \& Kapoor 1984). The microscopic observations were made under oil immersion by standard light microscopy to note down characters of appressorial mycelium, conidiophores, conidia, thyriothecia, ascus and ascospores used to identify species. Camera lucida drawings were also prepared to support the final confirmation of fungi.

\section{Results}

Three black mildew fungi were collected on aerial parts of infected plants during the course of mycological survey. Description and illustrations of these fungi along with a discussion on their taxonomy are presented as here.

\section{Taxonomy}

Schiffnerula celastri Hosag., Riju \& Sabeena, Indian J. Sci. Techn. 2(6):8, 2009.

(Figs. 1-2)

= Stigmella palawanensis Sydow, Philippine J. Sci. 9: 189, 1914; Sahni, Mycopath. Mycol. Appl. 23: 332, 1964.

= Sarcinella palawanensis (Sydow \& Sydow) Sahni, Mycopath. Mycol. Appl. 29: 241, 1966.

= Sarcinella paniculatae Verma, Tripathi \& R. K. Choudhary, Indian Phytopath. 52: 379, 1999.

= Clypeolella inversa Hohn sensu Thite \& Kulkarni, Indian Phytopath. 26: 76, 1973.Figs 1-2

Colonies amphigenous, black, dense, coalesced up to $4 \mathrm{~mm}$ in diameter; hyphae substraight to crooked, branching irregular at acute angles, opposite to alternate, loosely to closely reticulate, 3.1-4.0 $\mu \mathrm{m}$ wide, cells 13.2-46.5 × 3-4.5 $\mu \mathrm{m}$. Appressoria opposite, unicellular, sessile, globose, entire 6.6-11 $\times$ 6-9 $\mu \mathrm{m}$. Sexual morph:Thyriothecia scattered, orbicular, ovate, initially radiating, later central portion dissolved by exposing asci, up to $156 \mu \mathrm{m}$ in diameter, marginal cells radiating. Asci 5-8 per thyriothecia, globose, 8-spored, bitunicate, 15-28 $\mu \mathrm{m}$ in diameter. Ascospores 16.94-26 × 6-13 $\mu \mathrm{m}$, oblong, conglobate, uni-septate, constricted at the septum, remaining hyaline for some time, but turning brown at maturity. Asexual morph: Conidia of Questieriella 31.5-53 $\times 6-9.5 \mu \mathrm{m}$, scattered, free, not attached, curved, 3-septate, slightly constricted at the septa, tapering towards both ends, 31.5-53 $\times 6$ $9.5 \mu \mathrm{m}$. Sarcinella conidiophores produced lateral to the hyphae, single, straight to flexuous, macronematous, mononematous, 0-2- septate, 11-31 × 4-6 $\mu \mathrm{m}$. Conidiogenous cells monoblastic, integrated, mostly terminal, cylindrical. Sarcinella conidia 16.5-24.2 (20.24 \pm 2.78$) \mu \mathrm{m}$ in diameter, blastic, terminal, mostly sessile, solitary, dry, ovate to globose, sarciniform, cruciately septate, 2-8celled, constricted at the septa, wall smooth.

Material examined - India, Himachal Pradesh, Berthin (Distt. Bilaspur) 673 meters (2,208 ft), Tanda (Distt. Mandi) 760 meters (2,495 ft), and Chail Chowk (Distt. Mandi) 1400 metres (4,592 ft), on leaves of Celastrus paniculatus L. (Celastraceae), collected by A. K. Gautam, 26.10.2015 (AUMH 1034).

Notes - The fungus collected on Celastrus paniculatus was identified as Schiffnerula celastri and produced both asexual (Quistieriella and Sarcinella) and sexual morphs. The species has also reported previously from various localities of Kerala, Maharashtra, Karnataka and Uttar Pradesh. The Sarcinella morph of this fungus is also known from Uttar Pradesh. It is reported for the first time from Himachal Pradesh. 

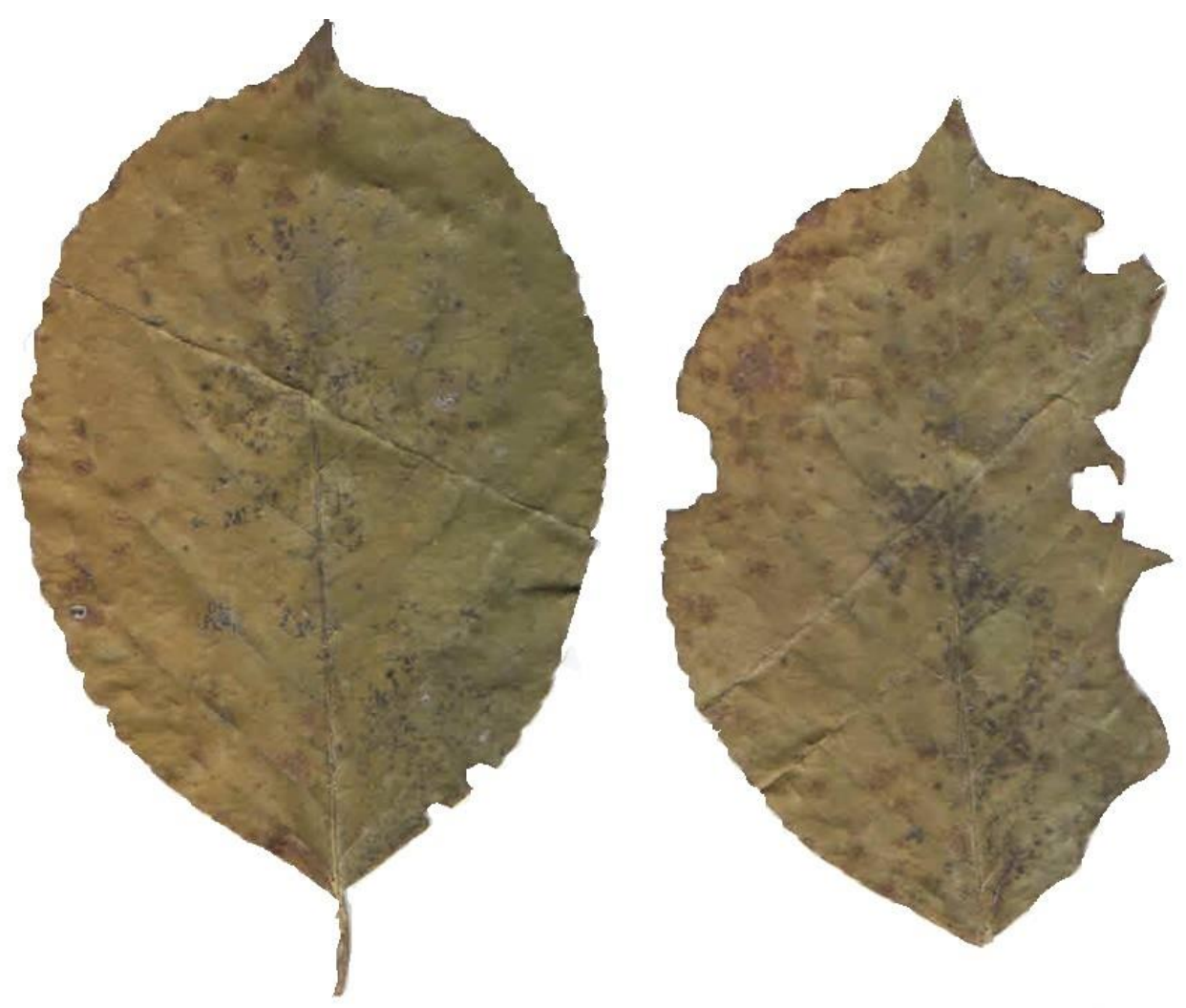

Fig. 1 - Black mildew infection on leaves of Celastrus paniculatus.

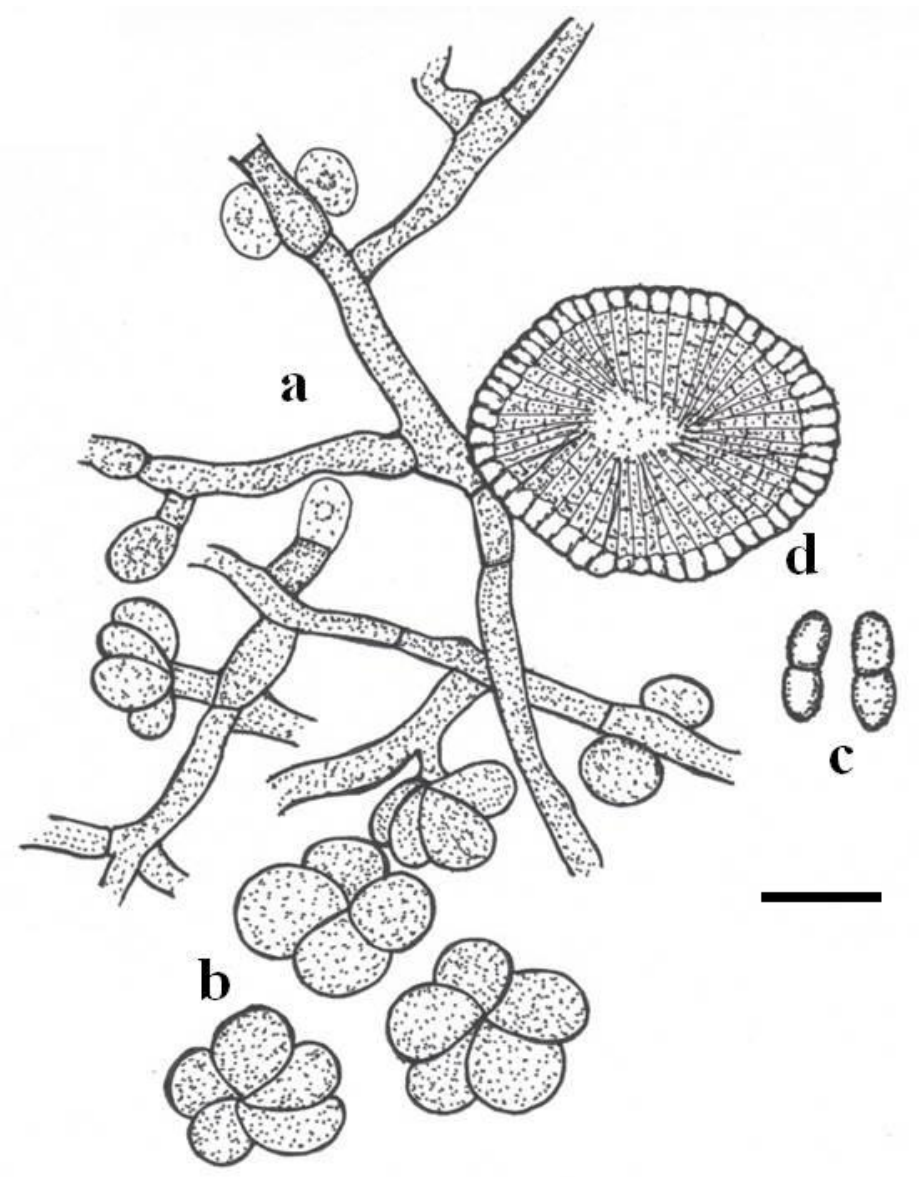

Fig. 2 - Schiffnerula celastri. a. Branched mycelium, b. Sarciniform conidia, c. Ascospores. d. Thyriothecia. (Scale bar: $20 \mu \mathrm{m}$ ) 
Sarcinella oreophila H. Sydow, Ann. Mycol. 35: 242, 1927.

(Figs. 3-4)

Colonies amphigenous, subdense, up to $5 \mathrm{~mm}$ in diameter, confluent. Hyphae pale brown, straight, branching irregular, at acute angles, loosely reticulate, cells 19-31 $\times 3-4.5 \mu \mathrm{m}$. Appressoria alternate to unilateral, unicellular, globose, margin entire, 4-7.5 $\times 5-6.5 \mu \mathrm{m}$. Sexual morph: Undetermined. Asexual morph: Conidiophores macronematous, micronematous, simple, straight, short, light brown, arise laterally from the hyphae, smooth, 3-5 $\times 4-5 \mu \mathrm{m}$. Conidiogenous cells integrated, terminal, monoblastic, cylindrical. Conidia $14.3-23.1 \mu \mathrm{m}$, simple, dry, solitary, acrogenous, globose, smooth, dark brown, constricted at the septa, cells 3-8, sarcinately arranged.

Material examined - India, Himachal Pradesh, Berthin (Distt. Bilaspur), 673 meters $(2,208 \mathrm{ft})$ and Mandi 760 meters (2,495 ft), on leaves of Carissa sp. (Apocynaceae), collected by A.K. Gautam, 14.11.2015 (AUMH 1035).

Note - This fungus collected on Carissa sp. was identified as Sarcinella oreophila. Two asexual morphs (Quistieriella and Sarcinella) were observed. The species has previously been reported only from Kerala. No reports are available from other part of the country. Therefore, present collection constitutes new record for north western Himalaya and second for India.
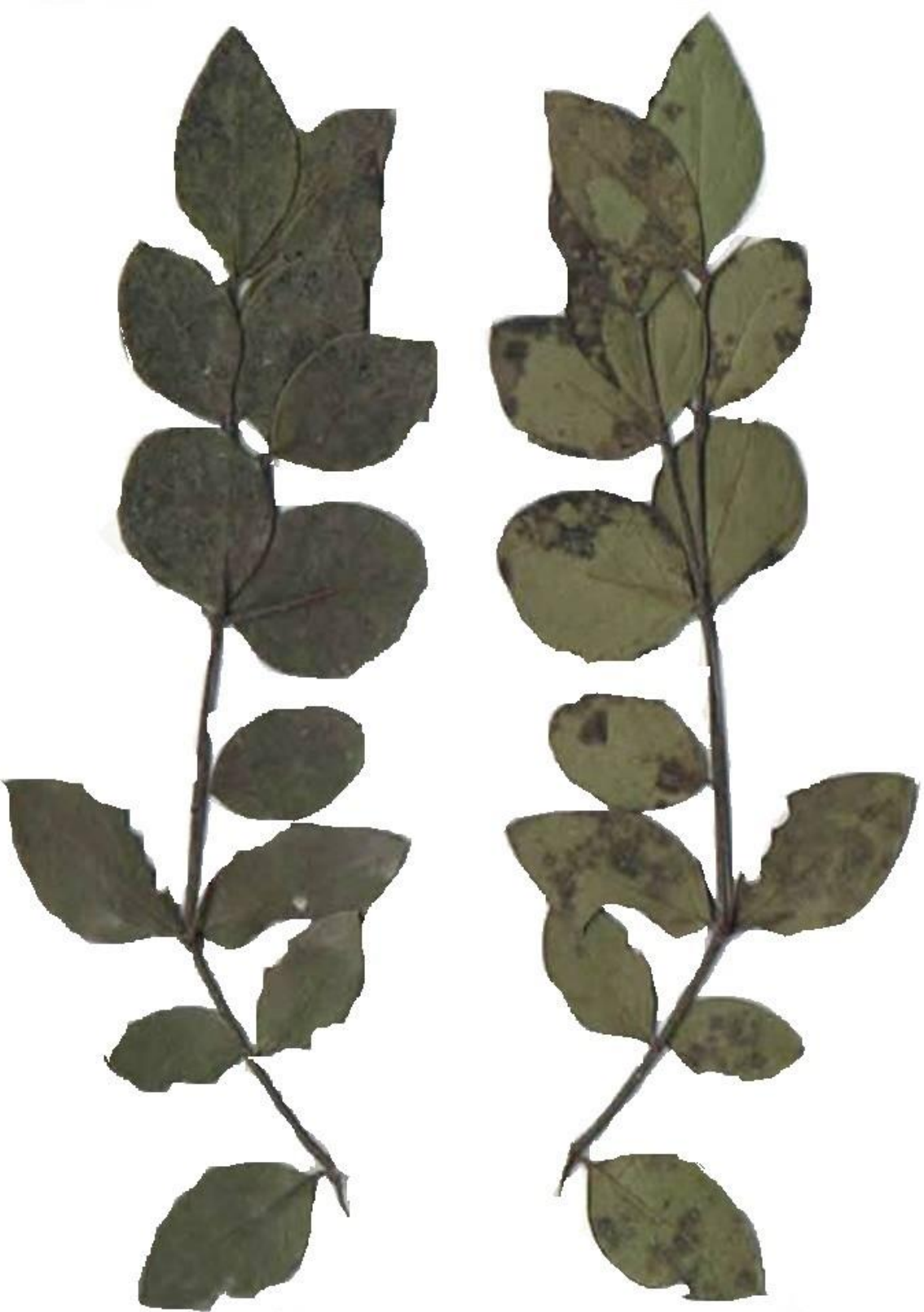

Fig. 3 - Black mildew infection on leaves of Carissa sp. 


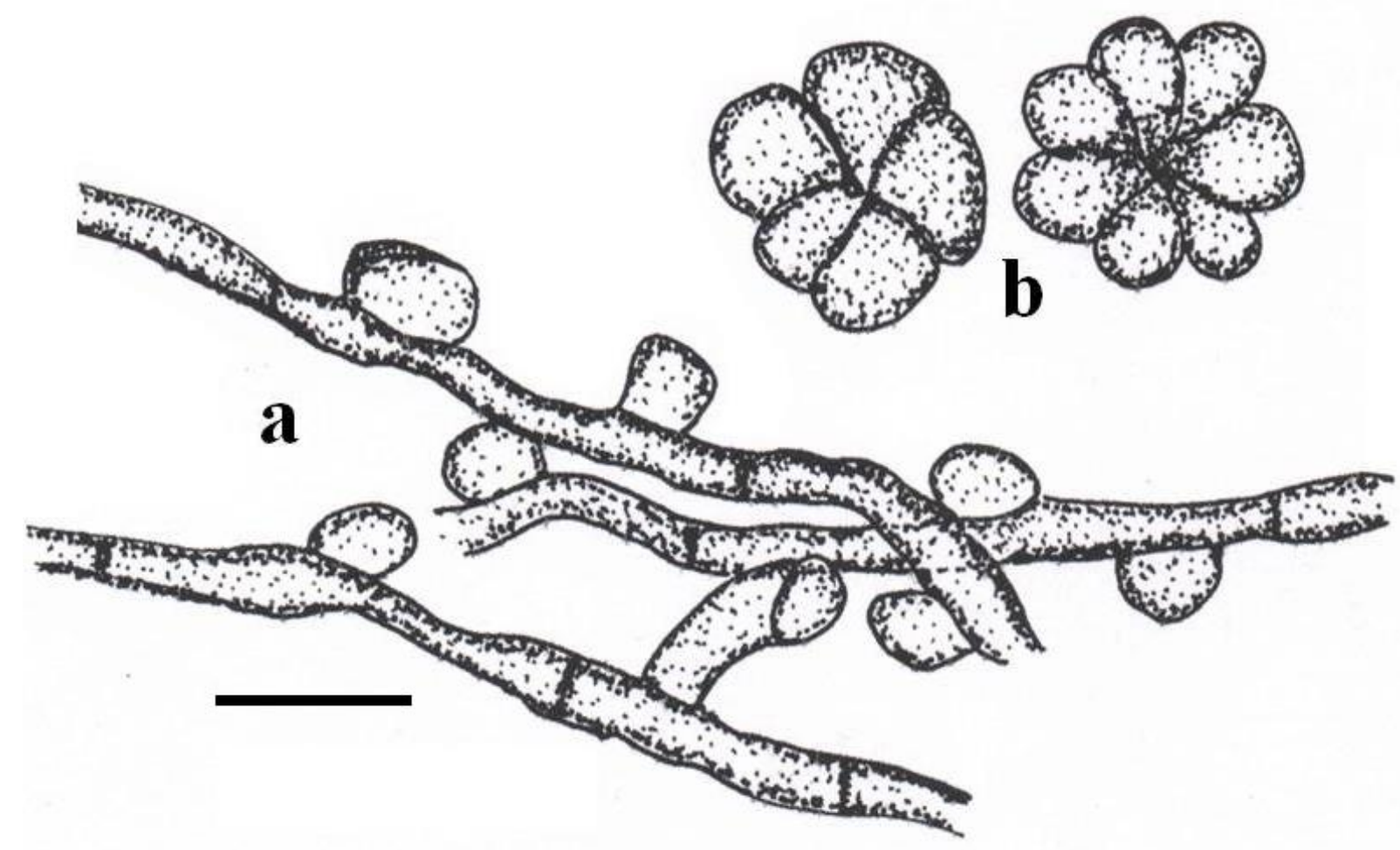

Fig. 4 - Sarcinella oreophila. a. Branched mycelium, b. Sarciniform conidia. (Scale bar: 20um)

Schiffnerula cryptostegiae Hosag. \& Jacob-Thomas, P1. Pathol. Quarantine 1(2), 131-204, 2011

(Figs. 5-6)

Colonies amphigenous, black, subdense, 2-5.5 mm in diameter, confluent. Hyphae pale brown, straight, branching irregular, at acute angles, loosely reticulate, cells $4.7-5.5 \times 2.2-4.5 \mu \mathrm{m}$. Appressoria alternate to unilateral, unicellular, globose, margin entire, 5- $11.5 \times 5.5-9 \mu \mathrm{m}$. Sexual morph: Thyriothecia scattered, orbicular, ovate, initially radiating, later central portion dissolved by exposing asci, up to $60 \mu \mathrm{m}$ in diameter, marginal cells radiating. Asexual morph: Conidiophores macronematous, micronematous, simple, straight, short, light brown, arise laterally from the hyphae, smooth, 3-5 $\times 4-5 \mu \mathrm{m}$. Conidiogenouscells integrated, terminal, monoblastic, cylindrical. Conidia $22-$ $33 \mu \mathrm{m}$, simple, dry, solitary, acrogenous, globose, smooth, dark brown, constricted at the septa, cells $3-$ 8, sarcinately arranged. Questeriella state present, slightly curved, 3-septate, constricted at the septa, end cells acute, $30-35 \times 10.5-12 \mu \mathrm{m}$.

Material examined - India, Himachal Pradesh, Berthin (Distt. Bilaspur), 673 meters (2,208 ft) and Mandi 760 meters (2,495 ft), on leaves of Cryptolepis buchanani Roem \& Schult (Apocynaceae), collected by A. K. Gautam, 13.12.2015 (AUMH 1036).

Note - Schiffnerula cryptostegiae was collected on C. buchananifrom Vazhachal Forests, Thrissur, Kerala. The Sarcinellastate of this fungus is known from Uttar Pradesh. It is reported here for first time from Himachal Pradesh.

\section{Discussion}

The black mildews namely Schiffnerula celastri, Sarcinella oreophila and Schiffnerula cryptostegiae were reported on Celastrus paniculatus, Carissa sp. and Cryptolepis buchanani respectively in the present study. These black mildew fungi have been reported previously from Kerela, Maharashtra, Karnataka and Uttar Pradesh (Srivastava et al. 1990; Verma et al. 1999; Hosagoudar 2011), but are unknown in Himachal Pradesh and surrounding areas. However, two black mildew fungi i.e. Schiffnerula girijae and Prillieuxina aeglicola (Gautam 2014; Gautam 2015) were reported on A. marmelos from the state. Therefore, present study contributes new additions to black mildew fungi, not only to the state, but also to North Western Himalaya. 

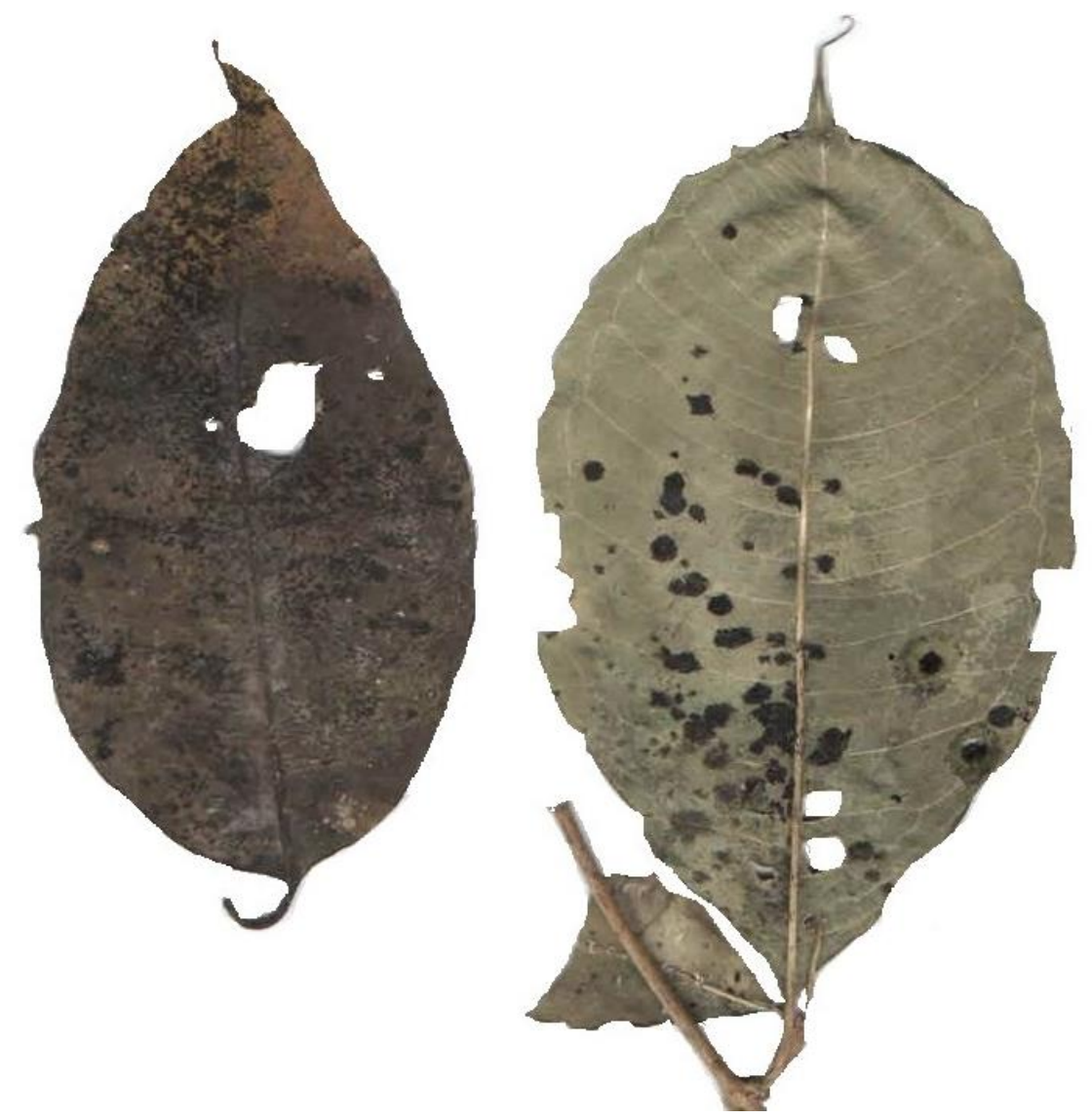

Fig. 5 - Black mildew infection on leaves of Cryptolepis buchanani.

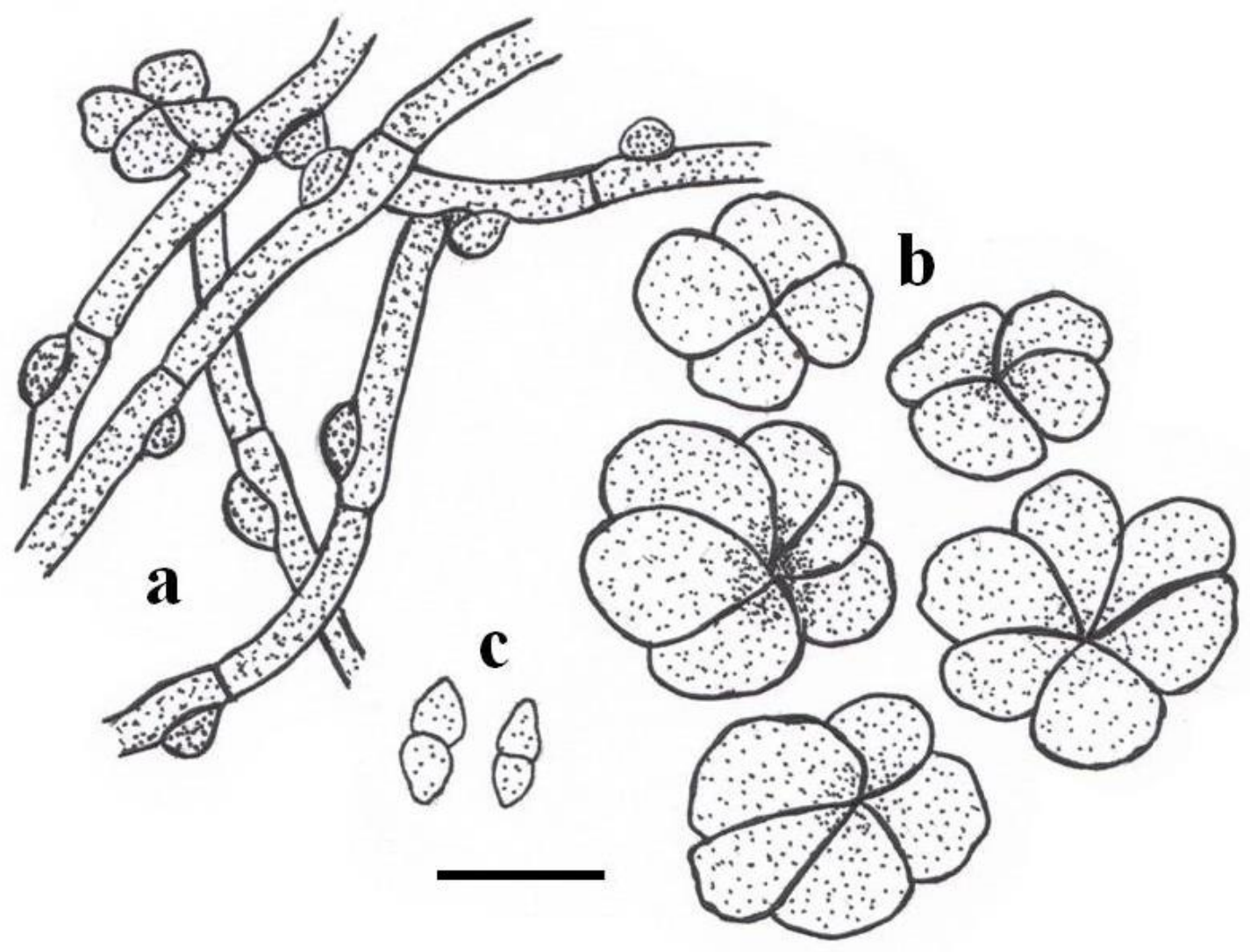

Fig. 6 - Schiffnerula cryptostegiae. a. Branched mycelium, b. Sarciniform conidi. C. Ascospores.

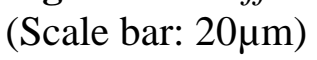




\section{Acknowledgements}

The authors are thankful to their respective organizations for providing laboratory facilities and providing support throughout the study.

\section{References}

Gautam AK 2014 - Occurrence of black mildew on Aegle marmelos at Himachal Pradesh, India. International Journal of Phytopathology 3 (3), 161-162.

Gautam AK 2015 - Prillieuxinaaeglicola sp. nov. (ascomycota), a new black mildew fungus from Himachal Pradesh, India. Current Research in Environmental \& Applied Mycology 5(1), 70 73.

Hansford CG 1961 - The Meliolineae. A monograph. Sydowia 2, 1-806.

Hosagoudar VB 2008 - Meliolales of India. Vol. II. Botanical Survey of India, Calcutta, pp. 390.

Hosagoudar VB 2011 - The genus Schiffnerula in India. Plant Pathology \& Quarantine 1(2), 131-204.

Hosagoudar VB, Agarwal DK 2008 - Taxonomic studies of Meliolales. Identification Manual. International Book Distributors, Dehra Dun, pp. 263.

Hosagoudar VB, Kapoor JN 1984 - New Technique of mounting meliolaceous fungi. Indian Phytopathogy 38, 548-549.

Srivastava N Chandra S, Gupta C 1990 - New species of foliicolous hyphomycete genus Sarcinella. Vegetos 3, 74-82.

Verma RC, Tripathi MS, Chaudhary RK 1999 - Three new species of black mildews from forest flora of north - Eastern Uttar Pradesh. Indian Phytopathology 52(4), 377-380. 